\title{
Applications of Fuzzy Analytic Hierarchy Process in Urban Mobility System
}

\author{
Uroš KRAMAR, Darja TOPOLŠEK
}

\begin{abstract}
Importance of urban mobility system is increasing from year to year. This is the reason why decision making process is increasingly complex requiring taking into account more and more different criteria. One of the important and commonly used techniques that support decision making processes is Analytic Hierarchy Process (AHP) while for the purpose of supporting a more realistic way of decision making, fuzzy logic is used. The paper examines the use of fuzzy analytical hierarchy process (FAHP) in the urban mobility system. With the use of systematic literature review (SLR) it categorises peer reviewed journals' articles related to the applications of FAHP in urban mobility system and extracted from Scopus and Web of science database, and analyses them methodologically. Papers were classified based on basic attributes of research papers, features of urban mobility system (UMS) where the FAHP was used, and use characteristics of the fuzzy analytic hierarchy process (FAHP). The results of this study indicated that the use of FAHP in urban mobility system is increasing with the first published paper in 2009. Our review has found that FAHP is used for very different purposes such as evaluation of customer expectations or citing a selection problem. Most often it is used in combination with other methods. Interestingly, there is only one paper that uses FAHP for decision making in the whole urban mobility system.
\end{abstract}

Keywords: fuzzy analytic hierarchy process; systematic literature review; urban mobility system; urban transport system

\section{INTRODUCTION}

Modern society depends on mobility. As pointed out by [1] mobility is a significant scope of social improvement both for individuals and for the whole country. The increasing dependence on high-quality mobility system also brings negative consequences that are evident through environment problems, traffic jams and congestion, which in turn reduces the degree of mobility. According to the United Nations, actions should be taken so that the transport system becomes more sustainable and that the provision of mobility becomes a priority of every transport policy [2].

For the efficient and effective operation of the mobility of the system it is necessary to provide complex and complete solutions, which will enable sustainable development. Such solutions, however, require the adoption of complex decisions, taking into account the various and also conflicting criteria. For creating productive judgments that satisfy all the appropriate gauges for judgment at various levels, Multi-Criteria Decision-Making (MCDM) methods are commonly applied. Between the various MCDM techniques recommended, the Analytic Hierarchy Process (AHP) suggested by Saaty [3] is well-known. When making a decision it is much easier for decision makers to articulate themselves through linguistic terms. As is claimed in [4] a decision-making approach can be considerably upgraded with a fuzzy linguistic model, and be applicable for individual judgements and assessment preferences. According to [5], fuzzy logic makes a more realistic way for such issues and to better deal with undetermined human judgments.

We can find many applications that use fuzzy AHP technique to solve various situations [4]. In Scopus database there are more than 2.479 papers that apply FAHP. Considering these circumstances, an analysis of usefulness of FAHP in particular areas becomes important.

However, to the best of our knowledge there has not been a study that has reviewed FAHP applications in urban mobility system. We consider this as an important gap in the literature and aim to contribute an up-to-date review of
FAHP applications in urban mobility system to fill the gap. So the purpose of this research is to explore the use of FAHP in the urban mobility system as one of frequently used methods for MCDM problems. It provides an overall review of the past researches and shows how FAHP can be used in urban mobility system. It also provides cases of the use of FAHP in urban mobility system, combined in one place, which can be useful for different practices and policies.

The structure of the paper is as follows. In the next section urban mobility is briefly described. Then we introduce FAHP in Section 3. In section four the methodology used is explained. Findings are introduced in section five. The paper finishes with research conclusions.

\section{URBAN MOBILITY}

Oxford English Dictionary defines "mobility" as "the ability to move or be moved freely and easily" [6]. According to [8], in the field of transport mobility is described as "the potential for movement" and the capability to get from point A to point B. Some authors [1] use the term transport mobility in conjunction with the gains derived from travel activities.

There is not a clear distinction between transport and mobility. In literature mobility and transport are often used together (see [9]). Generally speaking, though, "mobility is a broader concept than transport, as it refers not only to actual movement, always referring to the latter. When we talk about urban mobility it can be understood as urban transport of passengers and freight in relation to conurbations [10]. It includes users and their interaction, the transport system, vehicles and infrastructure and their interaction, impacts of transport and relevant tools in an urban context [10]. It is the ability to move between different activities sites [11] and represents a complex system with many subsystems. A comprehensive discussion on the difference between the transport and mobility goes beyond the intention of this research paper. For the purpose of our research, we will use the term mobility and focus on urban mobility. 
Modern approaches for regulating urban mobility systems require a holistic strategic approach with a mixed strategy between 'hardware' and 'software' oriented measures (see [12]) and with focus on more sustainable modes of travel such as public transport, walking and cycling. All this demonstrates the need for the adoption of integrated strategic decisions, which may be significantly more difficult because decisions are often complex and objectives contradictory.

\section{FUZZY AHP}

AHP, proposed by [3] and presented in 1970s', is one of widely used MCDM tools [13]. It consists of three basics parts: model structure, comparisons of the alternatives and the criteria and combined preferences. Besides AHP, there are several well-established MCDM models [13]; most popular ones are ELECTRE, PROMETHEE and TOPSIS [14]. AHP has been broadly used in solving various complex decision-making problems such as planning, defining the best alternative, resource allocation and customer expectations [13]. It has also been used in many different fields, for example technology and engineering, marketing, business, government, education and medicine which highlights the importance of research of AHP usage in different fields [13]. Regardless of its recognition, acceptance and simplicity in handling MCDM problems, the AHP is often criticized for its incapability to appropriately tackle the inherent unpredictability and unclearness [7]. Similarly, [14] emphasizes that the traditional AHP is not able to reflect the unclearness in human thinking style.

Uncertainty in preferences can be modelled using fuzzy set theory which was first introduced by Zadeh [15]. The fuzzy set theory uses linguistic terms to express decision maker preferences and has the ability and capacity to point out vague data. In fuzzy set terminology, the ratio supplied by the decision maker is a fuzzy number described by a membership function. Here, a membership function describes the degree with which elements in the judgment interval belong to the preference set [16]. Introduction of fuzzy linguistic factors instead of exact, crisp values can help a decision maker to use non-numerical terms for his/her subjective judgments and it can include the inexactness related to the decision maker's priorities. Therefore, it will remove the disadvantages of the static form of the basic scale in capturing uncertainty in the comparisons [7]. In order to include fuzzy linguistics factors in solving hierarchical multi-decision problems, FAHP, extension of AHP, is presented.

In FAHP pairwise comparison judgments are usually expressed by two different ordinary fuzzy numbers, i.e., triangular and trapezoidal fuzzy numbers [7]. An important part of the FAHP method is the process of determining weights to each criterion. To determine the weights, different approaches are used, such as Van Laarhoven and Pedrycz's approach, Buckley's fuzzy AHP or Chang's extent analysis method.

\section{METHODOLOGY}

Given the importance of mobility in urban environments and the complexity of the decision-making process, this paper examines scientific literature that uses FAHP in urban mobility system. To do such a research we used the systematic literature review (SLR) technique.

According to [17] and [18] from a methodological perspective, a literature review is a methodical, organized, straightforward, and consistent approach for analysing, assessing, and explaining the existing body of documents. Systematic reviews are described as literature reviews that are attached closely to a series of scientific approaches that strictly and exactly aim to limit systematic error (bias), primarily by trying to recognize, evaluate and incorporate all relevant research studies with the purpose of answering a specific question (or set of questions).

The SLR method was first presented in the 1990s in the field of medicine. It involves documenting all the procedures undertaken [19], [18] and as pointed out by [20], SLR can support the development of guidelines, as it encompasses the search, selection, critical evaluation and synthesis of primary research results. It differs from heavily statistics methods such as meta-analysis [19] and from traditional narrative reviews by being more systematic and explicit in the selection of the studies and employing rigorous and reproducible evaluation methods [21]. As argued by [22] one of the strengths of a SLR is its systematic methodology, therefore providing the required criticism in the performance of all research steps.

Following [18] the following stages are adopted in this review: 1. Formulation of clear and answerable research question; 2. determination of research database; 3. A detailed search of scientific papers with a help of a series of keywords; 4. Review and the elimination of irrelevant articles; 5. Examination of selected papers more thoroughly and analysis and classifications of articles; 6 . Concluding Remarks.

First stage in implementation of a systematic review is defining understandable and answerable question. According to [17] a research question is a precisely stated question that guides the review. To meet the needs of our research paper we formulated the following question: In what extent has the FAHP approach been used in the scientific literature to assist decision making in urban mobility system? More in detail, we wanted to answer the following two groups of sub questions: features of UMS where FAHP was used and use characteristics of FAHP.

For the purpose of answering the predefined research question, our search strategy has been composed of looking for relevant papers within extensive scientific literature, presented in peer-reviewed journals. For an initial generic search of the topic the articles were searched from Scopus Citation Databases using their web-based user interface at http://www.scopus.com. We chose Scopus database because "Scopus is the largest abstract and citation database of peer-reviewed literature" [23]. It covers over 20,500 headings from 5,000 publishers throughout the world, ensuring high quality and comprehensive search results [18]. As [19] claims Scopus holds a large number of established, eminent and widely-known journals with more than 41 million entries in its database and in terms of search functionality, it offers the opportunity to search simultaneously for keywords in an article title, abstract and keyword list thereby assuring that researcher can locate the required word within the above mentioned elements of a published paper. The same database has already been used 
by other researchers (see [23]). Additionally, we have also used Web of Science (WoS) database for a wider scope of articles.

After defining the database, we use "fuzzy AHP", "fuzzy analytic* hierarchy process" and FAHP, as keywords for searching in the field title, abstract or keywords. We found 3105 results in Scopus and 1092 in WOS. After limiting to document type: article, article in press, source type: journals and English language we found 1533 results in Scopus and 943 in WoS. In second stage we limited our research to next group of words: mobility, transport and transportation and we found 557 results in Scopus and 77 in WoS. According to our research question in the third stage we limited our results to urban and found 91 final results in Scopus and 6 in WOS.

This basic selection of references was first reviewed in order to evaluate their real importance for the topic of this research [18]. Thus, we excluded those that did not refer to any part of the mobility system or FAHP was not used or the paper was not related to the urban environment. Finally, a total of 19 papers published between 2009 and July 2016 were considered to be acceptable and suitable for our SLR. These papers were then analysed more thoroughly and classified according to some key elements which are shown in the next section.

\section{DISCUSSION}

According to our research question we analysed features of UMS where FAHP was used and characteristics of FAHP were used. Below key findings are presented.

\begin{tabular}{l} 
Table 1 Source of research papers per year \\
\begin{tabular}{|l|c|}
\hline \multicolumn{1}{|c|}{ Source of research papers } & Year \\
\hline $\begin{array}{l}\text { International Journal of Environmental Science And } \\
\text { Technology }\end{array}$ & 2009 \\
\hline Construction Management and Economics & 2010 \\
\hline $\begin{array}{l}\text { International Journal of Uncertainty, Fuzziness and } \\
\text { Knowledge-Based Systems }\end{array}$ & 2012 \\
\hline European Transport Trasporti Europei & 2013 \\
\hline Transport Policy & 2013 \\
\hline Total Quality Management and Business Excellence & 2013 \\
\hline Advances in Environmental Biology & 2014 \\
\hline Computational Intelligence and Neuroscience & 2014 \\
\hline European Transport Research Review & 2014 \\
\hline Journal of Applied Mathematics & 2014 \\
\hline Promet Traffic Traffico & 2014 \\
\hline Safety Science & 2014 \\
\hline Advances in Civil Engineering & 2014,2015 \\
\hline Habitat International & 2015 \\
\hline Transportation Research Part A Policy And Practice & 2015 \\
\hline Environmental Impact Assessment Review & 2016 \\
\hline $\begin{array}{l}\text { International Journal of Pavement Research And } \\
\text { Technology }\end{array}$ & 2016 \\
\hline Mathematical Problems in Engineering & 2016 \\
\hline Total & 19 research \\
\hline
\end{tabular} \\
\hline
\end{tabular}

Interestingly, the articles using FAHP in the field of urban mobility appear only in the last few years. First paper published in year 2009 was from [5]. It used FAHP with preference ranking organization method for classifying the transportation modes according to the environmental effects of them. The suggested methodology was used and tested in Marmara Region of Turkey. The increase in the number of research papers is visible from 2013 onwards. Most of them were published in 2014 [7]. In 2013, 2015 and 2016 there were three published research papers per year. It is expected that the number of papers in 2016 will increase.

Papers were published in 18 different publications (Tab. 1). Only in Advances in Civil Engineering there were two published papers (in year 2014 in 2015).

According to country/territory FAHP was most often used in Turkey (five research papers), four of them were used in Istanbul. Three research papers were used for urban mobility system in China and two in Iran, Kenya, United Kingdom and United States. All together FHAP was used in ten different countries.

Tab. 2 shows how many times individual research paper was citied. All together there were 112 citations. Most cited was [5] which ranked the transportation modes according to the environmental effects of them. Four research papers had more than 10 citations and three research papers were not cited.

Table 2 Number of citations of research papers

\begin{tabular}{|c|c|c|c|}
\hline Reference no & No of citations & Reference no & No of citations \\
\hline$[5]$ & 24 & {$[28]$} & 3 \\
\hline$[27]$ & 18 & {$[38]$} & 3 \\
\hline$[42]$ & 13 & {$[34]$} & 3 \\
\hline$[29]$ & 12 & {$[36]$} & 3 \\
\hline$[35]$ & 9 & {$[4]$} & 2 \\
\hline$[26]$ & 6 & {$[37]$} & 1 \\
\hline$[25]$ & 5 & {$[41]$} & 1 \\
\hline$[39]$ & 5 & {$[33]$} & 0 \\
\hline$[40]$ & 4 & {$[30]$} & 0 \\
\hline & & {$[32]$} & 0 \\
\hline
\end{tabular}

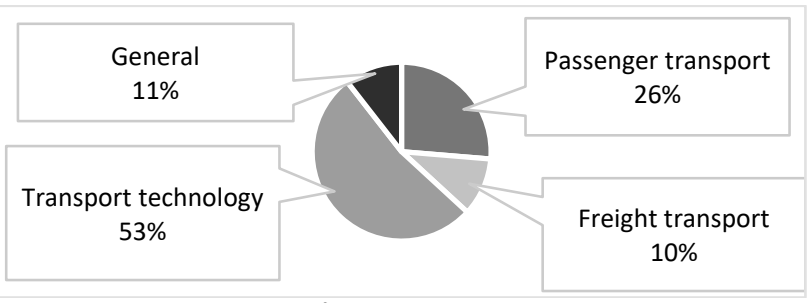

Figure 1 Analysis of research papers per main category

In Fig. 1, research papers are arranged according to categories of urban mobility system as in [24]. Regarding passenger transport, some papers used FAHP and SERVQUAL to evaluate customer satisfaction [25, 26], or to estimate the values of service gaps in delivered public transport service [27]. In category of freight transport, one paper used integrated FAHP and FTOPSIS for choosing central business district logistics scenario [28] and the other paper used FAHP to facilitate the employment of unpredictability in seaport operations [29]. Some paper examples for transport technology are: [36] used FAHP and VIKOR for prioritization of pavement maintenance, [30] used FAHP and GIS to determine the location of subsurface parking. Within the 'general' category there are papers which cannot be classified among the remaining three categories. Among them there is also one paper that is focusing on the whole system, namely to rank the transportation modes according to their environmental effects [5].

In regard to the classification in [24] and [31] further analysis was done according to the mobility sub-category. One can notice that the main subcategory where FAHP was used is public transport with 10 research papers (among them 5 in public bus system). Despite that, there is a strong 
tendency to present an integrated holistic approach in UMS that simultaneously requires complex decisions making, only one research paper used FAHP to comprehensively address the mobility system.

Table 3 Research papers according to transport sub-category

\begin{tabular}{|l|c|c|}
\hline $\begin{array}{c}\text { Research papers according to transport sub- } \\
\text { category }\end{array}$ & $\begin{array}{c}\text { Number of } \\
\text { papers }\end{array}$ & $\%$ \\
\hline Public transport - bus & 5 & 26 \\
\hline Public transport - rail & 2 & 11 \\
\hline Public transport - metro or subway & 3 & 16 \\
\hline Walking and cycling & 0 & 0 \\
\hline Road transport (flowing and stationary, cars) & 1 & 5 \\
\hline Road technology & 4 & 21 \\
\hline Urban logistics & 1 & 5 \\
\hline General (whole system, intermodality,...) & 2 & 11 \\
\hline Water & 1 & 5 \\
\hline Air & 0 & 0 \\
\hline
\end{tabular}

Table 4 The use of FAHP in conjunction with soft and hard measures in UMS

\section{Soft measures}

Hard measures

\begin{tabular}{|c|c|c|}
\hline 11 papers & $58 \%$ \\
\hline 8 papers & $42 \%$ \\
\hline
\end{tabular}

We analysed research papers regarding soft and hard measures (Tab. 4) and according to which criteria they used (Fig. 2). We used similar criteria classification as in [18]. Among research papers there are eleven papers in the field of soft measures and eight papers that cover hard measures, which shows that the use of FAHP was not limited only to the decision making process in combination with developing transport infrastructure.

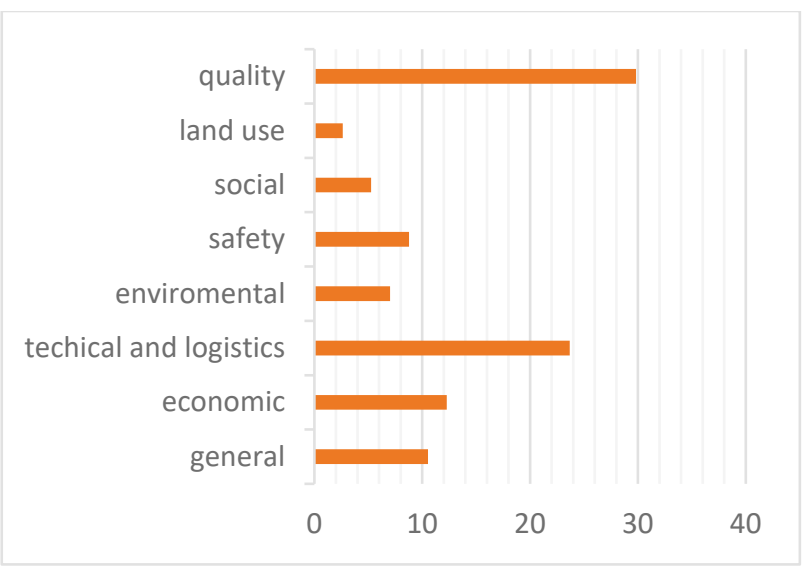

Figure 2 Type of criteria for decision-making in UMS

Diversification is also evident in the choice of criteria, where predominant criteria are in the field of quality and technical logistics. Quality criteria are present in a large number of papers (16 research papers). Technical and logistics criteria are also present in a large number of research papers (14 research papers). At least one economic criterion is present in 12 research papers. In the general group there are decision criteria like social-cultural criteria [30] or government support level [32]

We also analysed research papers according to the use of FHAP. The summary of use characteristics is shown in Tabs. 4, 5, 6 and 7.
Table 5 The use of fuzzy numbers

\begin{tabular}{|c|c|c|c|c|}
\hline $\begin{array}{c}\text { Fuzzy numbers } \\
\text { used }\end{array}$ & Triangular & Trapezoidal & $\begin{array}{c}\text { Not } \\
\text { specified }\end{array}$ & Other \\
\hline No. of papers & 13 & 1 & 4 & 1 \\
\hline
\end{tabular}

Table 6 Method for weight computation

\begin{tabular}{|l|c|c|c|c|c|}
\hline $\begin{array}{c}\text { Method for } \\
\text { weight } \\
\text { computation }\end{array}$ & $\begin{array}{c}\text { Buckley's } \\
\text { (1985) FAHP } \\
\text { algorithm }\end{array}$ & $\begin{array}{c}\text { Computing } \\
\text { fuzzy } \\
\text { eigenvalue }\end{array}$ & $\begin{array}{c}\text { Not } \\
\text { speci } \\
\text { fied }\end{array}$ & $\begin{array}{c}\text { Chang's } \\
(1992) \\
\text { extent } \\
\text { analysis }\end{array}$ & Other \\
\hline No. of papers & 7 & 4 & 1 & 4 & 3 \\
\hline
\end{tabular}

Table 7 Use of consistency check

\begin{tabular}{|c|c|c|c|c|}
\hline $\begin{array}{c}\text { Use of } \\
\text { consistency } \\
\text { check }\end{array}$ & $\begin{array}{c}\text { Not } \\
\text { used }\end{array}$ & $\begin{array}{c}\text { Used with } \\
\text { results shown }\end{array}$ & $\begin{array}{c}\text { Used but } \\
\text { results not } \\
\text { shown }\end{array}$ & Not needed \\
\hline No. of papers & 10 & 5 & 3 & 1 \\
\hline
\end{tabular}

Table 8 Use of defuzzification

\begin{tabular}{|l|l|l|l} 
Use of defuzzification & Used & Not used & Not specified \\
\hline
\end{tabular}
No. of papers

The most commonly used fuzzy numbers were triangular fuzzy numbers, which does not differ from applications in other fields. For weight computation the most used method was Buckley’s (1985) FAHP algorithm, followed by Chang's (1992) extent analysis and Computing fuzzy eigenvalue. It is interesting that ten research papers did not use consistency check, five used it and showed the results. One research paper explains that consistency check for their research was not needed [34]. Eight from 19 research papers used defuzzification for changing fuzzy into crisp numbers.

Tab. 10 shows that there is quite a wide variation of the use of FAHP in urban mobility system, from customer satisfaction $[34,35]$, infrastructure projects $[30,37,38$, 36], treatment of uncertainties [29] to environment impact evaluations [5, 4].

Regarding method combination FHAP was independently used two times namely to set up an assessment index system for the development level of urban public transport [32] and to make the multi-criteria evaluation of the existing rail systems for the assignment of the scarce sources [39]. Five times FAHP was used with TOPSIS [4, 28, 34, 40, 41] three times with SERVQUAL $[27,25,26]$ and two times with GIS [30], [37].

Regarding the selection of decision makers two research papers used users of UMS [27, 26], four research papers did not specify decision makers [34, 32, 30, 38] and 13 research papers used different type of experts.

According to the review of scientific papers we can conclude that the use of FAHP in urban mobility system increases through the years, which means that its useful value in multi-criteria decision-making problems is recognized. Its useful value is very wide, which means it can be used for taking simple or complex decisions to tackle various segments of the urban mobility system. Its utility is in its simplicity and convenience, but it is a sufficiently accurate method that may be used for significant managerial decisions. 
Table 9 Rewiewd papes according to authors and purpose of the research

Authors

Tadić, Zečević and

Krstić, 2014 [28]

Ouma, Yabann, Kirichu

and Tateishi, 2014 [37]

Aydin, Celik and

Gumus, 2015 [35]

Zhao, Tang and Ning,

2016 [33]

Bilişik, Erdoğan, Kaya

and Baraçli, 2013 [36]

Pashmakian and Saeed

Izadi 2014 [30]

Lupo, 2013 [26]

Zou, Dai, Yao, Jiang

and Guo, 2014 [32]

Ouma, Opudo and

Nyambenya, 2015 [40]

Zou and Li, 2010 [42]

Wey, 2015 [38]

Shafabakhsh,

Hadjihoseinlou and

Taghizadeh, 2014 [41]

Bilisik, Demirtaş,

Tuzkaya and Baraçl,

2014 [34]

John, Paraskevadakis,

Bury, Yang, Riahi and

Wang, 2014 [29]

Tuzkaya, 2009 [5]

Babashamsi, Golzadfar,

Yusoff, Ceylan and Nor,

2016 [25]

Ruiz-Padillo, Ruiz,

Torija and Ramos-

Ridao, 2016 [4]

Lupo, 2013 [26]

Sari, Behret, Kahraman

2012 [39]

\section{Purpose}

A new proposal of choosing the central business district logistics scenario, which is composed of different city logistics initiatives.

To take into account the vagueness type uncertainty detected and experienced in alternative bypass location determination

To assess level of customer satisfaction for the rail transit lines of Istanbul

To solve group decision-making support problem of emergency alternatives in Unattended Train Operation metro system of China

To evaluate customer satisfaction of public transportation system

To determine the location of subsurface parking selection in reducing the loss of historic neighbourhoods identification surrounding central area of Hamedan and appropriate response to the problem of citizen space and spatial needs

To conquer constraints of the traditional service assessment methods and to evaluate customer satisfaction with the public

urban transit service which is supplied in the city of Palermo

To establish an assessment index system for the development level of urban public transport consisting of a target layer, a criterion layer, and an index layer

to evaluate and compare FAHP and Fuzzy TOPSIS method for the subjective analysis of the pavement conditions for automated maintenance prioritization

To develop a comprehensive risk checklist associated with subway projects and a methodology to assess the risks at the early stage of a project

To find a solution for a site selection problem by employing the FAHP as the assurance region's weights

To select an appropriate public transportation system to access airport

To establish the best locations for bus garages to manage the maintenance and repair activities

To facilitate the employment of unpredictability in seaport operations and to optimize its performance effectiveness in a systematic manner

To rank the transportation modes according to the environmental effects of them

Prioritization of pavement maintenance alternatives

To select appropriate options against traffic noise in each of the road stretches included in the noise action plans To estimate the values of service gaps in public urban transport service delivered

To make the multi-criteria evaluation of the existing rail systems for the assignment of the scarce sources

Table 10 Features of FAHP use in UMS

\begin{tabular}{|c|c|c|c|c|}
\hline Authors & Combination method/technique & $\begin{array}{l}\text { No. of } \\
\text { criteria/sub } \\
\text { criteria }\end{array}$ & Selection of alternatives & No. of decision makers/Definition of experts \\
\hline $\begin{array}{l}\text { Tadić, Zečević and } \\
\text { Krstić, } 2014 \text { [28] }\end{array}$ & $\begin{array}{l}\text { Integrated FAHP-FTOPSIS } \\
\text { method }\end{array}$ & $10 / 0$ & $\begin{array}{l}3 \text { scenarios of the Central } \\
\text { Business Danube District } \\
\text { logistics system }\end{array}$ & $\begin{array}{l}\text { More than one / A number of stakeholders: } \\
\text { residents, shippers and receivers, logistics } \\
\text { providers and city government }\end{array}$ \\
\hline $\begin{array}{l}\text { Ouma, Yabann, } \\
\text { Kirichu and Tateishi, } \\
2014[37]\end{array}$ & $\begin{array}{l}\text { FAHP and GIS-based least cost } \\
\text { path (LCP) analysis }\end{array}$ & $3 / 9$ & 1 road & $\begin{array}{l}\text { More than one / Large number of experts: } \\
\text { Transportation engineers and planners }\end{array}$ \\
\hline $\begin{array}{l}\text { Aydin, Celik and } \\
\text { Gumus, } 2015 \text { [35] }\end{array}$ & $\begin{array}{l}\text { FAHP, Statistical analysis and } \\
\text { fuzzy-Choquet integral }\end{array}$ & $9 / 0$ & 6 rail transit lines & More than one / Professionals and academicians \\
\hline $\begin{array}{l}\text { Zhao, Tang and Ning, } \\
2016[33]\end{array}$ & $\begin{array}{l}\text { FAHP and Enhanced WOWA } \\
\text { operator }\end{array}$ & $3 / 0$ & $\begin{array}{l}5 \text { Emergency alternatives } \\
\text { of train fire. }\end{array}$ & $\begin{array}{l}5 \text { groups of decision makers / Traffic } \\
\text { dispatcher, Environment dispatcher, Passenger } \\
\text { Dispatcher, Vehicle Dispatcher, Power } \\
\text { dispatcher }\end{array}$ \\
\hline $\begin{array}{l}\text { Bilişik, Erdoğan, } \\
\text { Kaya and Baraçli, } \\
2013[36]\end{array}$ & $\begin{array}{l}\text { FAHP, SERVQUAL, the Delphi } \\
\text { method and TOPSIS }\end{array}$ & $5 / 33$ & $\begin{array}{l}4 \text { public transport } \\
\text { companies }\end{array}$ & $\begin{array}{l}3 \text { experts and more transport users / One } \\
\text { working in Istanbul Electric Tramway and } \\
\text { Tunnel company, the second an academician } \\
\text { offering studies on this topic, and the third one } \\
\text { both working in IETT company at an } \\
\text { administrative level and having academic } \\
\text { publications }\end{array}$ \\
\hline $\begin{array}{l}\text { Pashmakian and } \\
\text { Saeed Izadi } 2014 \text { [30] }\end{array}$ & FAHP and GIS & $7 / 17$ & $\begin{array}{l}4 \text { urban locations for under } \\
\text { subsurface parking }\end{array}$ & Not specified \\
\hline Lupo, 2013 [26] & $\begin{array}{l}\text { FAHP and SERVQUAL } \\
\text { discrepancy paradigm }\end{array}$ & $5 / 18$ & 1 Palermo transit service & 300 random customers \\
\hline $\begin{array}{l}\text { Zou, Dai, Yao, Jiang } \\
\text { and Guo, } 2014 \text { [32] }\end{array}$ & Only FAHP & $6 / 22$ & $\begin{array}{l}1 \text { present public transport } \\
\text { development }\end{array}$ & More than one / Not specified \\
\hline $\begin{array}{l}\text { Ouma, Opudo and } \\
\text { Nyambenya, } 2015 \\
{[40]}\end{array}$ & FAHP and FTOPSIS & $4 / 0$ & $\begin{array}{l}7 \text { pavement maintenance } \\
\text { alternatives }\end{array}$ & $\begin{array}{l}10 \text { / Pavement engineers, inspectors, and } \\
\text { transport planners }\end{array}$ \\
\hline
\end{tabular}




\begin{tabular}{|c|c|c|c|c|}
\hline Authors & Combination method/technique & $\begin{array}{l}\text { No. of } \\
\text { criteria/sub } \\
\text { criteria }\end{array}$ & Selection of alternatives & No. of decision makers/Definition of experts \\
\hline Zou and $\mathrm{Li}, 2010$ [42] & FAHP and Risk checklist & $6 / 30$ & 1 city subway line & $\begin{array}{l}5 \text { / different weights for experts Contract } \\
\text { Manager Consultant Department head Project } \\
\text { manager Senior engineer. Two criteria: (1) each } \\
\text { must have more than five years' working } \\
\text { experience in subway projects; and (2) each } \\
\text { must be a member of senior management staff } \\
\text { or a senior engineer }\end{array}$ \\
\hline Wey, 2015 [38] & $\begin{array}{l}\text { FAHP and Data Envelopment } \\
\text { Analysis (DEA) model with } \\
\text { assurance region approach }\end{array}$ & $9 / 0$ & $\begin{array}{l}7 \text { possible transit station } \\
\text { sites }\end{array}$ & $6 /$ not specified \\
\hline $\begin{array}{l}\text { Shafabakhsh, } \\
\text { Hadjihoseinlou and } \\
\text { Taghizadeh, } 2014 \text { [41] }\end{array}$ & FAHP and TOPSIS & $9 / 0$ & $\begin{array}{l}3 \text { modes to access airport: } \\
\text { train, bus with } 25 \\
\text { passenger capacity and van } \\
\text { shuttle with } 5 \text { seats and a } \\
\text { space for passengers' } \\
\text { luggage }\end{array}$ & $\begin{array}{l}3 \text { groups of decision makers / involving } \\
\text { transportation experts, airport operators and } \\
\text { employees beside passengers inhabited in city } \\
\text { of Sari that have used this airport as a point of } \\
\text { their travel at least } 5 \text { times }\end{array}$ \\
\hline $\begin{array}{l}\text { Bilisik, Demirtaş, } \\
\text { Tuzkaya and Baraçl, } \\
2014 \text { [34] }\end{array}$ & $\begin{array}{l}\text { FAHP and Integrated MCDM } \\
\text { technique and fuzzy axiomatic } \\
\text { design (AD) technique }\end{array}$ & $6 / 18$ & $\begin{array}{l}6 \text { different urban garage } \\
\text { locations }\end{array}$ & More than one / not specified \\
\hline $\begin{array}{l}\text { John, Paraskevadakis, } \\
\text { Bury, Yang, Riahi and } \\
\text { Wang, 2014 [29] }\end{array}$ & $\begin{array}{l}\text { FAHP and An evidential } \\
\text { reasoning (ER) approach, fuzzy } \\
\text { set theory and expected utility. }\end{array}$ & $5 / 20$ & 0 & $\begin{array}{l}3 \text { / A senior operations manager who has been } \\
\text { involved with port operational services for over } \\
20 \text { years. A senior marine and safety engineer } \\
\text { who has been involved in maritime and port } \\
\text { operational management for over } 20 \text { years. A } \\
\text { chief superintendent of maritime transportation } \\
\text { systems who has been involved with maritime } \\
\text { operations for over } 20 \text { years. }\end{array}$ \\
\hline Tuzkaya, 2009 [5] & $\begin{array}{l}\text { FAHP and Preference ranking } \\
\text { organization method }\end{array}$ & $9 / 0$ & $\begin{array}{l}5 \text { alternatives: Road, } \\
\text { Railway, Sea, Air and } \\
\text { Multimodal }\end{array}$ & $\begin{array}{l}\text { More than one / Decision makers: } \\
\text { academicians, government, municipality, } \\
\text { environmental associations and logistics firms }\end{array}$ \\
\hline $\begin{array}{l}\text { Babashamsi, } \\
\text { Golzadfar, Yusoff, } \\
\text { Ceylan and Nor, } 2016 \\
{[25]}\end{array}$ & FAHP and VIKOR method & $5 / 0$ & 3 examples of pavements & $\begin{array}{l}25 \text { / Experts in pavement design and } \\
\text { management }\end{array}$ \\
\hline $\begin{array}{l}\text { Ruiz-Padillo, Ruiz, } \\
\text { Torija and Ramos- } \\
\text { Ridao, } 2016 \text { [4] }\end{array}$ & $\begin{array}{l}\text { FAHP, Discrete multi-criteria } \\
\text { analysis methods (weighted sum) } \\
\text { and ELECTRE and TOPSIS }\end{array}$ & $5 / 17$ & $\begin{array}{l}5 \text { alternatives and more sub } \\
\text { alternatives Noise barriers, } \\
\text { Low noise pavements, } \\
\text { Traffic management, } \\
\text { Building insulation, } \\
\text { Covering the road } \\
\end{array}$ & $\begin{array}{l}65 \text { / Technical staff from public administration, } \\
\text { technical staff from engineering consulting } \\
\text { firms, academic experts }\end{array}$ \\
\hline Lupo, 2013 [26] & FAHP and SERVQUAL & $5 / 18$ & $\begin{array}{l}\text { Bus urban transport system } \\
\text { in Palermo }\end{array}$ & $\begin{array}{l}\text { About } 300 \text { customers and a total of } 50 \\
\text { respondents between decision-makers and } \\
\text { service employers have } \\
\text { been interviewed }\end{array}$ \\
\hline $\begin{array}{l}\text { Sari, Behret, } \\
\text { Kahraman, } 2012 \text { [39] }\end{array}$ & Only FAHP & $4 / 13$ & $\begin{array}{l}4 \text { main rail systems of } \\
\text { Istanbul }\end{array}$ & $\begin{array}{l}5 \text { experts ( } 2 \text { academicians and } 3 \text { managers from } \\
\text { public companies). }\end{array}$ \\
\hline
\end{tabular}

\section{CONCLUSIONS}

Throughout the paper, we reviewed articles published in recognized journals that used FAHP methodology for solving problems in the field of urban mobility systems. More in detail we analysed features of UMS where FAHP was used and used characteristics of FAHP. We note that this methodology was started rather late to be applied in this field (since 2009), but its usefulness increases throughout the years. The purpose of FAHP methodology is diverse. Most often it was used in transport technology and in the sub-category of public urban transport. It was used for decision making in combination with both soft as hard measures. Interestingly only one research paper used FAHP on whole UMS, despite the fact that the political guidelines highlight the holistic problem solving in UMS with inclusion of all transport modes. The features of FAHP use show that most often employed type of criteria were quality, technical and logistics. When we analysed the use of the consistency check, we found that eight research papers have used consistency check and ten research papers were not checked for decision consistency.
This paper presents a new systematic review of applications of FAHP in the field of urban mobility system, which can be used for further research. It would be interesting to investigate what Fuzzy MCDM methods still exist in the field of urban mobility, what is the frequency of these methods and for which purpose they are being used.

\section{REFERENCES}

[1] Spinney, J. E. L., Scott, D. M., \& Newbold, K. B. (2009). Transport mobility benefits and quality of life: A time-use perspective of elderly Canadians. Transport Policy, 16(1), 111. https://doi.org/10.1016/j.tranpol.2009.01.002

[2] UN-Habitat. (2013). Policy Directions: Planning and Design for Sustainable Urban Mobility: Global Report on Human Settlements. http://unhabitat.org/books/planning-and-design -for-sustainable-urban-mobilityglobal-report-on-humansettlements-2013-policy-directions/ (20.09.2015)

[3] Saaty, T. L. (1980). The Analytic Hierarchy Process. McGraw Hill Company, New York.

[4] Ruiz-Padillo, A., Ruiz, D. P., Torija, A. J., \& Ramos-Ridao, Á. (2016). Selection of suitable alternatives to reduce the 
environmental impact of road traffic noise using a fuzzy multi-criteria decision model. Environ Impact Assess Rev., 61, 8-18. https://doi.org/10.1016/j.eiar.2016.06.003

[5] Tuzkaya, U. R. (2009). Evaluating the environmental effects of transportation modes using an integrated methodology and an application. Int J Environ Sci Technol, 6(2), 277-290. https://doi.org/10.1007/BF03327632

[6] (2016). Oxford Dictionaries. Oxford University press. Mobility. http://www.oxforddictionaries.com/ (15.06.2016)

[7] Javanbarg, M. B., Scawthorn, C., Kiyono, J., \& Shahbodaghkhan, B. (2012). Fuzzy AHP-based multicriteria decision making systems using particle swarm optimization. Expert Sys Appl, 39(1), 960-966. https://doi.org/10.1016/j.eswa.2011.07.095

[8] Handy, S. (2002). Accessibility- vs. Mobility-enhancing strategies for addressing automobile dependence in the US. Prepared for the European Conference of Ministers of Transport.

[9] Gomina Mama, F., Yang, Z., Xia, D. (2015). Strategies for sustainable urban transport: A case study of Cotonou, Benin. Int J Eng Res Afr., 13, 9-20. https://doi.org/10.4028/www.scientific.net/JERA.13.9

[10] Euroforum. (2006). Draft paper State-of-the-Art Urban Mobility.

[11] Hanson, S. \& Giuliano, G. (2004). The Geography of Urban Transportation. The Guilfor Press, New York.

[12] Pressl, R. \& Reiter, K. (2001). Mobility Management and Travel Awareness. PORTAL Written Material.

[13] Hassan, M. N., Hawas, Y. E., \& Ahmed, K. (2013). A multidimensional framework for evaluating the transit service performance. Transportation Research Part A: Policy and Practice, 50, 47-61. https://doi.org/10.1016/j.tra.2013.01.041

[14] Büyüközkan, G. \& Çifçi, G. (2012). A combined fuzzy AHP and fuzzy TOPSIS based strategic analysis of electronic service quality in healthcare industry. Expert Sys Appl, 39(3), 2341-2354. https://doi.org/10.1016/j.eswa.2011.08.061

[15] Zadeh, L. A. (1965). Fuzzy sets. Information and Control, 8, 338-353. https://doi.org/10.1016/S0019-9958(65)90241-X

[16] Leung, L. C. \& Cao, D. (2000). On consistency and ranking of alternatives in fuzzy AHP. Eur. J Oper. Res., 124(1), 102113. https://doi.org/10.1016/S0377-2217(99)00118-6

[17] Fink, A. (1998). Conducting research literature reviews: From paper to the internet. Sage, Thousand Oaks, CA, USA.

[18] Camargo Pérez, J., Carrillo, M. H., Montoya-Torres, J. R. (2014). Multi-criteria approaches for urban passenger transport systems: a literature review. Ann Oper Res., 226(1), 69-87. https://doi.org/10.1007/s10479-014-1681-8

[19] Ginieis, M., Sánchez-Rebull, M., \& Campa-Planas, F. (2012). The academic journal literature on air transport: Analysis using systematic literature review methodology. $J$ Air Transp Manage., 19(1), 31-35. https://doi.org/10.1016/j.jairtraman.2011.12.005

[20] Cook, D. J., Greengold, N. L., Ellrodt, A. G., \& Weingarten S. R. (1997). The relation between systematic reviews and practice guidelines. Ann Intern Med., 127(3), 210-216. https://doi.org/10.7326/0003-4819-127-3-199708010-00006

[21] Delbufalo, E. (2012). Outcomes of inter-organizational trust in supply chain relationships: A systematic literature review and a meta-analysis of the empirical evidence. Supply Chain Manage, 17(4), 377-402. https://doi.org/10.1108/13598541211246549

[22] Oliveira, J. B., Lima, R. S., Montevechi, J. A. B. (2016). Perspectives and relationships in Supply Chain Simulation: A systematic literature review. Simul Model Pract Theory, 62, 166-191. https://doi.org/10.1016/.simpat.2016.02.001

[23] Scopus. (2016). The largest database of peer-reviewed literature. Elsevier. https://www.elsevier.com/solutions/ scopus (01.06.2016)

[24] Macharis, C. \& Bernardini, A. (2015). Reviewing the use of multi-criteria decision analysis for the evaluation of transport projects: Time for a multi-actor approach. Transport Policy, 37, 177-186. https://doi.org/10.1016/j.tranpol.2014.11.002

[25] Babashamsi, P., Golzadfar, A., Yusoff, N. I. M., Ceylan, H., Nor, N. G. M. (2016). Integrated fuzzy analytic hierarchy process and VIKOR method in the prioritization of pavement maintenance activities. Int J Pavement Res Technol, 9(2), 112-120. https://doi.org/10.1016/j.jprt.2016.03.002

[26] Lupo, T. (2013). Strategic analysis of transit service quality using fuzzy AHP methodology. Eur. Transp. Trasporti Eur. 53.

[27] Lupo T. (2013). Handling stakeholder uncertain judgments in strategic transport service analyses. Transport Policy, 29, 54-63. https://doi.org/10.1016/j.tranpol.2013.04.002

[28] Tadić, S. R., Zečević, S. M., \& Krstić, M. D. (2014). Ranking of logistics system scenarios for central business district. Promet Traffic Traffico, 26(2), 159-167. https://doi.org/10.7307/ptt.v26i2.1349

[29] John, A., Paraskevadakis, D., Bury, A., Yang, Z., Riahi, R., \& Wang, J. (2014). An integrated fuzzy risk assessment for seaport operations. Saf. Sci., 68, 180-194. https://doi.org/10.1016/j.ssci.2014.04.001

[30] Pashmakian, N. \& Saeed Izadi, M. (2014). Optimizatized planning and location of under-subsurface parking on the southern side of the central area of Hamadan using AHP and GIS. Adv Environ Biol., 8(12), 328-343.

[31] ELTIS. The SUMP concept. http://www.eltis.org/mobilityplans/sump-concep (20.2.2017)

[32] Zou, L., Dai, H., Yao, E., Jiang, T., \& Guo, H. (2014). Research on assessment methods for urban public transport development in China. Comput Intell Neurosci. https://doi.org/10.1155/2014/941347

[33] Zhao, B., Tang, T., \& Ning, B. (2016). Applying hybrid decision-making method based on fuzzy AHP-WOWA operator for emergency alternative evaluation of unattended train operation metro system. Math Probl Eng. https://doi.org/10.1155/2016/4105079

[34] Bilisik, O. N., Demirtaş, N., Tuzkaya, U. R., \& Baraçl, H. (2014). Garage location selection for public transportation system in Istanbul: An integrated fuzzy AHP and fuzzy axiomatic design based approach. $J$ Appl Math. https://doi.org/10.1155/2014/541232

[35] Aydin, N., Celik, E., \& Gumus, A. T. (2015). A hierarchical customer satisfaction framework for evaluating rail transit systems of Istanbul. Transp Res Part a Policy Pract., 77, 6181. https://doi.org/10.1016/j.tra.2015.03.029

[36] Bilișik, Ö. N., Erdoğan, M., Kaya, I., \& Baraçli, H. (2013). A hybrid fuzzy methodology to evaluate customer satisfaction in a public transportation system for Istanbul. Total Qual Manage Bus Excellence, 24(9-10), 1141-1159. https://doi.org/10.1080/14783363.2013.809942

[37] Ouma, Y. O., Yabann, C., Kirichu, M., \& Tateishi, R. (2014). Optimization of urban highway bypass horizontal alignment: A methodological overview of intelligent spatial MCDA approach using fuzzy AHP and GIS. Adv Civ Eng. https://doi.org/10.1155/2014/182568

[38] Wey, W. (2015). Smart growth and transit-oriented development planning in site selection for a new metro transit station in Taipei, Taiwan. Habitat Int., 47, 158-168. https://doi.org/10.1016/j.habitatint.2015.01.020

[39] Sari, I. U., Behret, H., \& Kahraman, C. (2012). Risk governance of urban rail systems using fuzzy AHP: The case of Istanbul. Int $J$ Uncertainty Fuzziness Knowledge Based Syst, 20(SUPPL. 1), 67-79. https://doi.org/10.1142/S0218488512400053

[40] Ouma, Y. O., Opudo, J., \& Nyambenya, S. (2015). Comparison of Fuzzy AHP and Fuzzy TOPSIS for Road Pavement Maintenance Prioritization: Methodological Exposition and Case Study. Adv Civ Eng.

[41] Shafabakhsh, G. A., Hadjihoseinlou, M., \& Taghizadeh, S. A. (2014). Selecting the appropriate public transportation 
system to access the Sari International Airport by fuzzy decision making. Eur Transp Res Rev., 6(3), 277-285. https://doi.org/10.1007/s12544-013-0128-7

[42] Zou, P. X. W. \& Li, J. (2010). Risk identification and assessment in subway projects: Case study of Nanjing Subway Line 2. Constr Manage Econ., 28(12), 1219-1238. https://doi.org/10.1080/01446193.2010.519781

\section{Contact information:}

Uroš KRAMAR, M.C.A, Assistant

University of Maribor,

Faculty of Logistics,

Mariborska cesta 7, 3000 Celje, Slovenia

uros.kramar@um.si

Darja TOPOLŠEK, Assoc. Prof. PhD

University of Maribor,

Faculty of Logistics,

Mariborska cesta 7, 3000 Celje, Slovenia

darja.topolsek@um.si 